\title{
Model Internalisasi Budaya Organisasi di Institut Pertanian Bogor
}

\author{
Neila Komalasari Noor \\ Alumni Departemen Manajemen, Fakultas Ekonomi dan Manajemen \\ Institut Pertanian Bogor \\ Erlin Trisyulianti \\ Departemen Manajemen, Fakultas Ekonomi dan Manajemen \\ Institut Pertanian Bogor \\ Email: erlinatr@ipb.ac.id
}

\begin{abstract}
Bogor Agricultural University (IPB) is one of popular university in Indonesia, it was concern to the provided of the human resources which have good quality and competent. That's seven values of corporate culture are academic excellent, spiritualism, persevering, teamwork, empathy, responsible, and commitment. The objectives of this research are: (1) to identification organization culture in IPB, (2) to know the application of organization culture in IPB, (3) to recommend the model of internalization organization culture. This research used by descriptive analysis and Analysis Hierarchy Process (AHP) for analyzing internalization organization's culture in Bogor Agricultural University. According to the survey, dept interview and literary analysis, the organization culture in IPB is including in power culture, person culture, and achievement culture. The application of organization's culture in IPB is not maximal practice yet. The barrier of organization culture did not legitimate by Academic Senator, so the program that implementation organization culture is not yet. The factors that support organization culture in IPB is support from institution and human resource in IPB. The factor most influence in organization culture internalization in IPB is leadership. The actor most influence in organization culture internalization in IPB is head of university in IPB. The most influence objectives in organization culture internalization are actualization vision and mission organization. The alternative scenario in organization culture internalization is implementation learning organization in IPB.
\end{abstract}

Key word: IPB, organization culture, internalization.

\section{Pendahuluan}

Dewasa ini, semakin ketatnya kompetisi antara organisasi swasta dan publik yang diakibatkan oleh adanya globalisasi menuntut setiap organisasi untuk melakukan pengelolaan lebih baik dalam segala aspek. Selain dari segi pelayanan, salah satu hal yang terpenting adalah pengelolaan Sumber Daya Manusia (SDM). Hal ini dikarenakan SDM merupakan elemen penting dalam menjalankan kegiatan operasional di suatu organisasi. Untuk mewujudkan SDM yang bermutu serta meiliki keunggulan bersaing 
maka dibutuhkan adanya suatu budaya organisasi yang dapat digunakan untuk mengarahkan karyawan dalam bekerja agar sesuai dengan yang diharapkan oleh organisasi tersebut.

Organisasi dibentuk untuk mencapai suatu tujuan bersama. Tujuan tersebut merupakan tujuan organisasi yang disusun agar setiap anggotanya dapat mencapai tujuannya, harus dipertahankan, serta diperbesar kontribusinya dalam pencapaian tujuan organisasi. Hal ini menyebabkan organisasi harus peka terhadap internalisasi budaya organisasi, apakah sesuai dengan kebutuhan karyawan untuk mencapai tujuan organisasi.

Institut Pertanian Bogor (IPB) sebagai salah satu lembaga pendidikan tinggi negeri di Indonesia ikut berperan dalam penyediaan SDM yang bermutu dan kompeten. Penyedia SDM yang bermutu yang dimaksud adalah menghasilkan mahasiswa yang bermutu sehingga nantinya dapat menjadi SDM yang siap terjun di dunia kerja. Oleh karena itu, IPB juga harus memiliki SDM yang bermutu pula, baik dari pihak dosen maupun staf penunjang lain.

Salah satu cara untuk membentuk SDM yang bermutu adalah dengan menerapkan budaya organisasi yang kuat. Rektor IPB pada tanggal 13 Februari 2008 meluncurkan tujuh nilai budaya korporat, yaitu keunggulan akademik, spritualisme, gigih, senang bekerja sama, empati/peduli, tanggung jawab, dan komitmen.

\section{Metode Penelitian}

Penelitian ini menggunakan analisis deskriptif serta metode AHP untuk menganalisis dan merekomendasikan model internalisasi budaya organisasi di Institut Pertanian Bogor. Penggunaan analisis deskriptif adalah untuk melihat bagaimana penerapan budaya organisasi di IPB. Penggunaan AHP adalah untuk menindaklanjuti hasil dari analisis deskriptif, kemudian merekomendasikan model yang tepat dalam menerapkan internalisasi budaya organisasi di IPB. Kerangka pemikiran penelitian ini dapat dilihat pada Gambar 1. 


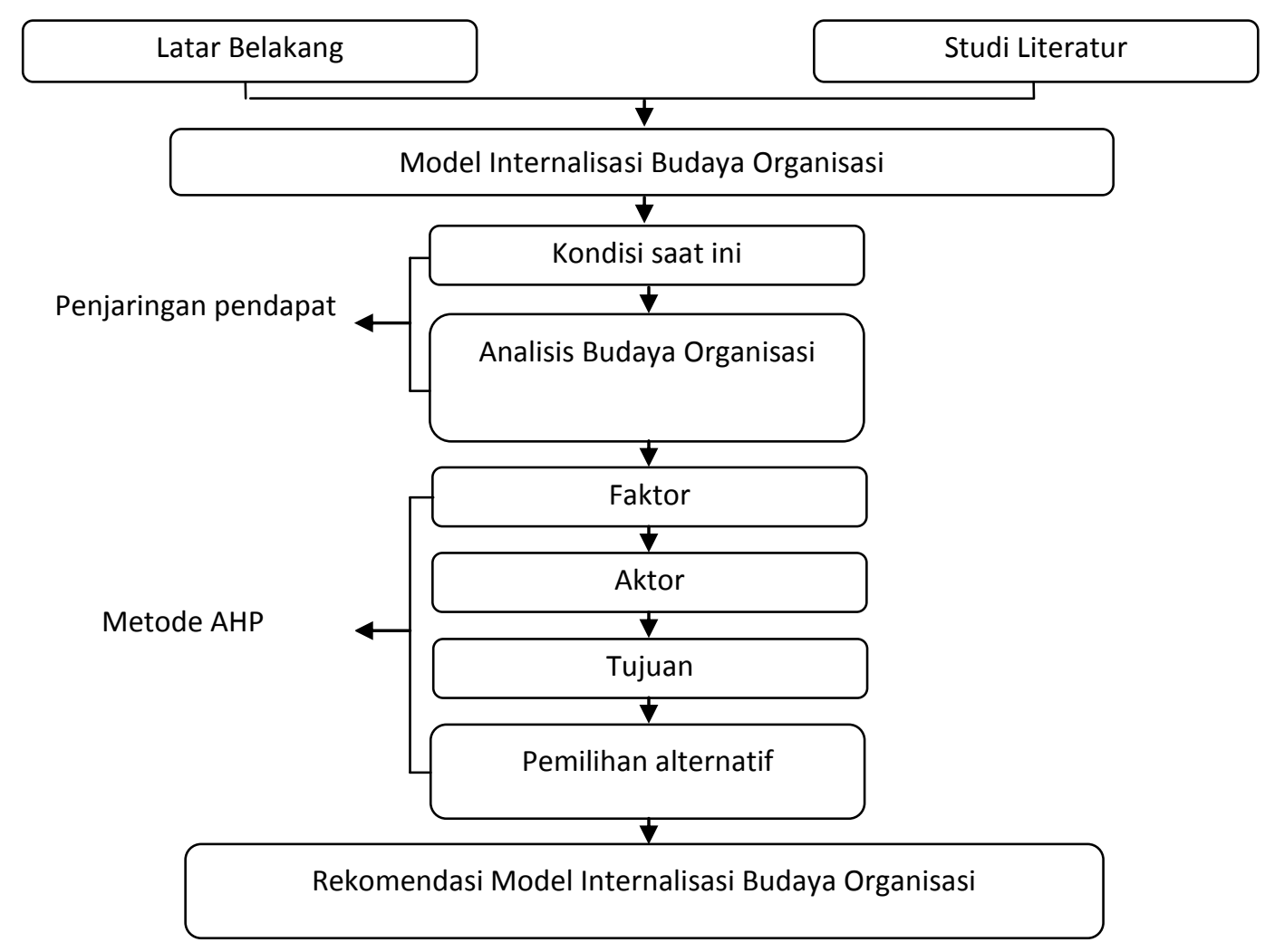

Gambar 1. Kerangka pemikiran penelitian

Kegiatan penelitian ini dilaksanakan selama tiga bulan yaitu pada bulan April sampai dengan bulan Juni 2009 dan mengambil lokasi di Institut Pertanian Bogor (IPB), Darmaga, Bogor, Jawa Barat.

Data yang dikumpulkan dalam penelitian ini adalah data primer dan data sekunder. Data primer merupakan data yang diperoleh secara langsung dari sumber atau objek yang diteliti baik melalui wawancara dengan pihak-pihak yang terkait maupun melalui pengamatan secara langsung di lokasi. Data sekunder diperoleh dari studi literatur, baik berupa jurnal, buku-buku, serta sumber-sumber lain yang menunjang penelitian.

Pengolahan data pada penelitian ini menggunakan metode AHP (Analytical Hierarchy Process), karena:

1. AHP memberikan solusi dengan proses formulasi yang mempertimbangkan datadata kuantitatif dan kualitatif.

2. AHP mempunyai kemampuan untuk mengatasi masalah yang kompleks dan kurang terstruktur dan tidak dapat diselesaikan dengan model matematika biasa.

3. AHP dapat mengarahkan proses pengambilan keputusan dengan mengidentifikasi dan menimbang kriteria yang dipilih, menganalisis data yang berhasil dikumpulkan dari kriteria tersebut dan tentunya proses pengambilan keputusan dapat berlangsung lebih cepat dan efisien (Saaty, 1991)

4. AHP mampu menciptakan suatu hasil yang representatif dengan memadukan beberapa pendapat pakar. Di mana kualitas yang dihasilkan tergantung pada ketepatan pemilihan pakar serta proses penyusunan bobot yang dilakukan oleh peneliti. 
Penilaian dilakukan dengan cara membandingkan komponen-komponen tersebut secara berpasangan dengan nilai yang merupakan skala komparasi yang dikeluarkan oleh Saaty (1991) sesuai dengan penilaian sehingga membentuk matriks persegi (n x n). Dengan menggunakan rumus matematika dalam proses hierarki analitik, data hasil diolah untuk mengetahui konsistensi indeks dan konsistensi rasio matriks pendapat individu. Jika matriks pendapat individu tersebut tidak konsisten, maka dilakukan revisi pendapat. Setelah itu dilakukan kembali pengolahan data hingga menghasilkan vektor prioritas sistem untuk masing-masing alternatif.

Formulasi Matematika, jika C1, C2,..., Cn merupakan elemen-elemen suatu level dalam hirarki, maka w1, w2,..., wn didefinisikan sebagai bobot dari setiap elemen terhadap suatu elemen pada tingkat di atasnya.

Apabila $\mathrm{Ci}$ dibandingkan dengan $\mathrm{Cj}$, maka didefinisikan sebagai nilai yang mengidentifikasikan besarnya kepentingan (kekuatan) $\mathrm{Ci}$ terhadap $\mathrm{Cj}$. Nilai aij=1/aij merupakan perbandingan kebalikannya. Nilai-nilai di atas akan membentuk matrik segi

\section{Hasil Penelitian}

\section{III.1. Analisis Deskriptif}

Analisis deskriptif diambil dari penjaringan pendapat atau wawancara beberapa pakar yang berkaitan serta mengerti mengenai budaya organisasi di IPB. Berdasarkan budaya organisasi IPB atau yang sering disebut sebagai tujuh nilai budaya korporat mulai diterapkan pada tahun 2008. Tujuh nilai budaya korporat ini adalah budaya baru yang diambil dari nilai-nilai yang sudah ada sebelumnya di lingkungan kampus IPB yang kemudian dirumuskan menjadi suatu budaya organisasi yang dapat dijalankan dalam aktivitas sehari-hari warga IPB. Proses perumusan awal budaya organisasi IPB ini berjalan dengan baik yang kemudian dilanjutkan dengan proses prasosialisasi yang mendapat banyak masukkan melalui pendekatan institusional maupun pendekatan pakar.

Tujuan atau latar belakang dari perumusan budaya organisasi ini adalah IPB ingin memiliki suatu budaya organisasi di mana sebelumnya IPB belum memiliki budaya organisasi untuk diterapkan.

Berdasarkan semua nilai-nilai yang ada di lingkungan IPB maka dirumuskanlah tujuh nilai budaya korporat IPB, yaitu:

1. Keunggulan Akademik

Mengembangkan budaya akademik yang jujur, obyektif, taat azas, ilmiah, manusiawi, nasionalis, inovatif, visioner, dan mandiri.

2. Spiritualisme

Bekerja berdasarkan nilai-nilai ibadah dan keimanan, keseimbangan hak dan kewajiban, keseimbangan berusaha dan berserah diri, keikhlasan, introspeksi, serta ahlak mulia.

3. Gigih

Senantiasa bersemangat, bekerja dengan cerdas, tidak mudah putus asa, berkesinambungan, fokus pada proses dan tujuan, serta bervariasi dalam strategi.

4. Senang Bekerja Sama

Menikmati sinergi, kolaborasi, dan jaringan kerja melalui sikap saling menghargai, saling membutuhkan, dan saling mengingatkan. 


\section{Empati atau Peduli}

Aktif dalam mendengarkan dan memahami orang lain berdasarkan keberpihakan yang adil serta kepekaan pada lingkungan.

6. Tanggung Jawab

Mampu menyesuaikan diri dalam tugas, tidak egois, serta cepat dan tepat dalam melaksanakan pelayanan prima.

\section{Komitmen}

Mampu dan mau bekerja secara konsekuen, konsisten, ramah, santun, dan sesuai dengan ketentuan yang sudah ada.

Ketujuh nilai budaya korporat IPB tidak ada satu nilai budaya organisasi pun yang menonjol. Hal ini dikarenakan semua nilai budaya harus seimbang, mempunyai bobot yang sama dan memiliki saling keterkaitan satu sama lain untuk mencapai visi, misi, serta tujuan organisasi.

Sosialisasi yang pertama kali dilakukan adalah melalui pengukuhan tujuh nilai budaya korporat IPB di Rabuan Bersama pada tanggal 13 Februari 2008. Rabuan itu dihadiri oleh Rektor, Wakil-wakil Rektor, Direktur- direktur, Kepala kantor, serta Dekan.

Penerapan nilai budaya korporat IPB diampu oleh Pusat Pengembangan Sumber Daya Manusia bekerja sama dengan Direktorat Sumber Daya Manusia dan Administrasi. Penerapan budaya organisasi di IPB belum dilaksanakan secara maksimal, karena budaya organisasi ini baru disosialisasikan sekali dan belum ada sosialisasi lanjutan serta belum ada program - program internalisasinya.

Budaya organisasi IPB mempunyai fungsi sebagai ciri khas atau keunikan tertentu, sebagai referensi atau acuan berbudaya (subculture), sebagai nilai yang harus dijalankan, sebagai cara untuk mencapai visi dan tujuan organisasi, sebagai kepribadian dan tutunan bagi anggotanya.

Budaya organisasi IPB ini termasuk ke dalam beberapa jenis budaya organisasi atau merupakan campuran dari beberapa jenis budaya organisasi, diantaranya adalah Power culture, Role culture, Task culture, Person culture, Support culture, Achievement culture. Namun yang paling mendekati adalah power culture, person culture, achievement culture.

Budaya organisasi IPB ini tidak mempunyai kelemahan secara konsep karena konsep yang ada pada budaya organisasi IPB ini merupakan cerminan dari semua nilai positif yang ada di lingkungan IPB. Namun, kelemahan budaya organisasi IPB ini terletak pada penginternalisasiannya, dimana belum ada kebijakan yang berkaitan dengan implementasi budaya organisasi tersebut. Semua budaya organisasi IPB ini apabila dijalankan secara seimbang maka akan diperoleh suatu budaya organisasi yang kuat.

Dalam perumusan budaya organisasi IPB ini tidak terdapat hambatan, seluruh pimpinan unit (institusional) ikut berperan aktif dan responsif dalam memberikan masukan. Hambatan yang muncul adalah setelah diadakan sosialisasi pertama kali atau penginternalisasian. Sosialisasi seharusnya dilakukan berkesinambungan atau kontinu karena untuk menginternalisasikan budaya organisasi tidak cukup dilakukan sosialisasi satu kali saja. Selain itu, untuk melakukan sosialisasi kepada karyawan harus dilakukan dengan cara transfer nilai yang sebaik mungkin dan bersifat persuasive agar tidak 
terjadi distorsi yang menyebabkan penerimaan atau pemahaman terhadap budaya organisasi menjadi berbeda. Hambatan yang muncul lainnya adalah belum disahkannya budaya organisasi ini oleh Senat Akademik (SA), sehingga belum adanya program atau kebijakan nyata yang mencerminkan pengimplementasian budaya organisasi.

Faktor-faktor pendukung budaya organisasi IPB adalah adanya dukungan dari kelembagaan dan SDM yang ada di IPB. Faktor pendukung pertama adalah dukungan dari kelembagaan yaitu top management dalam hal ini adalah Rektor serta dukungan dari lembaga atau organ normatif akademik (Senat Akademik), lembaga non akademik (Majelis Wali Amanat), dan Dewan Guru Besar. Faktor pendukung yang berikutnya adalah dukungan dari dua kelompok SDM yaitu dosen dan tenaga kependidikan (pegawai) serta mahasiswa (lembaga kemahasiswaan karena salah satu tugas lembaga kemahasiswaan adalah mengembangkan kegiatan kemahasiswaan).

Dari hasil wawancara serta studi literatur diperoleh beberapa faktor, aktor, serta tujuan yang berpengaruh terhadap internalisasi budaya organisasi di IPB. Ada lima faktor atau komponen yang terlibat dan berpengaruh dalam penerapan budaya organisasi, yaitu: informasi, perilaku, hierarki, kepemimpinan, serta tim atau kelompok.

Ada empat aktor yang terlibat dalam internalisasi budaya organisasi di IPB, yaitu: Rektor IPB, Direktur atau Kepala Kantor, Dekan, Ketua Departemen. Dari hasil wawancara serta studi literatur, diperoleh tiga tujuan yang ingin dicapai dalam internalisasi budaya organisasi di IPB, yaitu mengaktualisasikan visi dan misi organisasi, mengembangkan organisasi, dan terapi organisasi.

Berdasarkan hasil studi literatur dan wawancara dengan pihak-pihak yang mengerti serta berkaitan dengan penyusunan budaya organisasi di IPB diperoleh lima factor atau komponen yang berpengaruh terhadap internalisasi budaya organisasi di IPB. Kelima faktor tersebut adalah informasi, perilaku, hierarki, kepemimpinan dan tim atau kelompok.

1. Informasi (IF)

Informasi ini meliputi teknologi informasi serta semua sistem informasi. Dalam penerapan budaya organisasi diperlukan informasi yang lengkap bagi seluruh anggota organisasi agar proses penginternalisasian dapat berjalan dengan cepat serta tepat sesuai dengan tujuan.

2. Perilaku (PR)

Perilaku adalah tanggapan atau reaksi individu terhadap rangsangan atau lingkungan atau perubahan. Dalam penerapan budaya diperlukan perilaku yang baik dari para anggota organisasi agar proses penginternalisasian budaya organisasi dapat berjalan dengan baik.

3. Hierarki (HR)

Hierarki ini meliputi struktur organisasi, urutan tingkatan atau jenjang jabatan. Hierarki ini lebih banyak memberikan kendali bagi anggota organisasi. Hirarki ini merupakan pola interaksi dan koordinasi yang dirancang oleh manajemen untuk menghubungkan tugas-tugas individu dan kelompok karyawan dalam mencapai tujuan organisasi. 
4. Kepemimpinan (KP)

Salah satu komponen yang terpenting dalam internalisasi budaya organisasi adalah kepemimpinan. Di mana kepemimpinan merupakan cara memimpin. Seorang pemimpin sangat berpengaruh terhadap penerapan budaya organisasi.

5. Tim atau Kelompok (TM)

Tim ini merupaka kelompok formal yang terdiri dari individu-individu yang saling tergantung dan bertanggung jawab atas tercapainya sasaran. Tim ini juga merupakan komponen terpenting dalam penerapan budaya organisasi.

Aktor yang terlibat dalam internalisasi budaya organisasi di IPB adalah Rektor, Direktur atau Kepala Kantor, Dekan, dan Ketua Departemen.

1. Rektor (R)

Rektor merupakan top management di suatu universitas yang juga merupakan pengambil keputusan tertinggi. Rektor sangat menentukan bagaimana organisasi dijalankan dengan segala kebijakan-kebijakannya.

2. Direktur atau Kepala Kantor (DR)

Direktur atau Kepala Kantor merupakan unit yang menjalankan kegiatan operasional. Direktur menjadi pimpinan pertama yang mengetahui bagaimana kondisi kerja dan penerapan budaya organisasi di lapangan.

3. Dekan (D)

Dekan merupakan perpanjangan tangan rektor, atau dengan kata lain dekan merupakan top management di Fakultas. Dekan memiliki cakupan yang lebih fokus pada Fakultas. Dekan menjadi pihak yang mempertimbangkan segala bentuk kebijakan-kebijakan yang ditetapkan dalam organisasi.

4. Ketua Departemen (K)

Ketua Departemen merupakan pimpinan yang sangat dekat hubungannya dengan karyawan dan mahasiswa dalam menjalankan kegiatan sehari-hari organisasi. Ketua Departemen menjadi pimpinan pertama yang mengetahui bagaimana kondisi kerja dan penerapan budaya organisasi di lapangan.

1. Mengaktualisasikan Visi dan Misi organisasi (AVM)

Tujuan utama dari penerapan budaya organisasi adalah mencapai atau mewujudkan visi dan misi organisasi atau dengan kata lain budaya organisasi adalah alat pencapaian visi dan misi organisasi.

2. Mengembangkan Organisasi (KO)

Budaya organisasi ini dirancang untuk mengembangkan organisasi dapat dilakukan dengan review, revision dan reenginering. Perubahan-perubahan itu dilakukan secara bertahap dan perlahan demi perkembangan organisasi.

3. Terapi Organisasi (TO)

Budaya organisasi dirancang sebagai alat terapi organisasi. Terapi organisasi ini dilakukan apabila organisasi mengalami masalah yang memerlukan penanganan dengan segera. Terapi organisasi dapat dilakukan dengan revolusi, reformasi, koreksi, readjustment, dan improvement. Perubahan-perubahan ini dilakukan secara cepat untuk memperbaiki atau menangani masalah yang ada di organisasi tersebut. 
Alternatif yang dapat dipilih dalam penerapan Model Internalisasi Budaya Organisasi di IPB adalah melalui sosialisasi, lokakarya, learning organization, melalui forum pertemuan dan melalui training.

1. Sosialisasi (SO)

Penerapan model internalisasi budaya organisasi melalui sosialisasi yang dimaksud adalah dengan pengenalan awal budaya organisasi. Budaya organisasi disosialisasikan atau didifusikan dan diajarkan kepada setiap anggota organisasi baru. Isi budaya organisasi diperkenalkan dan diajarkan serta diterapkan dalam kegiatan organisasi.

2. Lokakarya (LK)

Penerapan model internalisasi budaya organisasi melalui lokakarya yang dimaksud adalah pertemuan para ahli (pakar) untuk membahas masalah praktis atau yang bersangkutan dengan pelaksanaan dalam bidang keahliannya.

3. Learning Organization (LO)

Penerapan model internalisasi budaya organisasi yaitu dengan learning organization atau organisasi pembelajaran adalah organisasi yang telah mengembangkan kemampuan untuk terus-menerus beradaptasi dan berubah karena semua anggota berperan aktif dalam mengidentifikasi dan menyelesaikan masalah-masalah yang berkaitan dengan pekerjaan.

4. Forum Pertemuan (FP)

Penerapan model internalisasi budaya organisasi yaitu melalui forum pertemuan. Forum pertemuan ini dilakukan rutin untuk menginternalisasi budaya organisasi ke setiap anggota organisasi. Contoh dari forum pertemuan ini adalah rabuan, rapat koordinasi, pertemuan rutin, dan lain-lain.

5. Training (TR)

Penerapan model internalisasi budaya organisasi yaitu melalui training atau pelatihan dapat dilakukan dengan on the job training yaitu pelatihan yang dilakukan saat anggota organisasi melakukan tugasnya atau pekerjaannya.

III.2. Analisis Pemilihan Alternatif Strategi Penerapan Model Internalisasi Budaya Organisasi di IPB

Analisis pemilihan alternatif strategi dimulai dengan penyusunan struktur (hierarki). Berdasarkan faktor-faktor yang mempengaruhi, aktor yang terlibat serta tujuan yang ingin dicapai maka disusun struktur hierarki yang terdiri dari lima tingkat, dengan tingkat satu adalah fokus (ultimate goal), tingkat dua adalah faktor yang mempengaruhi (faktor), tingkat tiga adalah aktor yang terlibat (actor), tingkat empat adalah tujuan yang ingin dicapai (objective) dan tingkat kelima adalah alternatifalternatif yang dapat dipilih untuk mencapai tujuan yang diharapkan (alternative). Penyusunan hierarki berdasarkan hasil wawancara dengan pihak pakar, baik yang terlibat secara langsung maupun tidak langsung. Struktur hierarki yang telah disusun menjadi dasar dalam pembuatan kuesioner yang kemudian akan diberikan kepada responden atau pakar untuk dimintai pendapatnya mengenai pemilihan strategi.

Pengolahan data dilakukan pada setiap tingkat terhadap elemen pada tingkat di atasnya. Dari hasil pengolahan AHP didapat dua proses pengolahan yaitu pengolahan horizontal yang menunjukkan besarnya tingkat pengaruh suatu elemen pada satu 
tingkat terhadap tingkat di atasnya dan pengolahan vertikal yang digunakan untuk menyusun prioritas pengaruh setiap elemen tingkat tertentu terhadap sasaran utama.

Pengolahan data secara horizontal akan memperlihatkan tingkat pengaruh antara satu elemen pada satu tingkat terhadap tingkat di atasnya. Pengolahan horizontal ini dibagi menjadi empat bagian yaitu pengolahan horizontal tingkat dua, tingkat tiga, tingkat empat, dan tingkat lima. Analisis tingkat dua merupakan analisis faktor-faktor yang mempengaruhi dalam penyusunan strategi penerapan model internalisasi budaya organisasi di IPB, analisis tingkat tiga merupakan analisis aktor-aktor yang terlibat, analisis tingkat empat merupakan analisis tujuan yang ingin dicapai serta analisis tingkat lima adalah analisis alternatif strategi yang dapat dipilih.

Pengolahan pada tingkat dua untuk menganalisis faktor-faktor yang berpengaruh terhadap penentuan strategi penerapan model internalisasi budaya organisasi di IPB. Berdasarkan pengolahan data dengan AHP dengan menggunakan expert choice 2000 dan Microsoft excel 2007 diperoleh bahwa komponen sebagai faktor yang paling berpengaruh dalam penerapan model internalisasi budaya organisasi di IPB adala kepemimpinan dengan prioritas 0,429 (Tabel 2 ). Faktor-faktor yang menjadi prioritas selanjutnya dalam pemilihan strategi adalah perilaku dengan bobot 0,232 , informasi dengan bobot 0,122 , hieraki dengan bobot 0,119 , dan yang terakhir adalah tim dengan bobot 0,098 .

Tabel 1. Prioritas Elemen Faktor Penyusun Strategi Penerapan Model Internalisasi Budaya Organisasi di IPB

\begin{tabular}{lc}
\hline \multicolumn{1}{c}{ Elemen Faktor } & Bobot \\
\hline Informasi (IF) & 0,122 \\
Perilaku (PR) & 0,232 \\
Hirarki (HR) & 0,119 \\
Kepemimpinan (KP) & 0,429 \\
Tim (TM) & 0,098 \\
\hline
\end{tabular}

Komponen kepemimpinan menjadi prioritas utama karena komponen tersebut berdasarkan hasil wawancara pakar dan studi literatur sangat diperlukan bagi internalisasi budaya organisasi. Budaya organisasi akan lebih mudah diinternalisasikan apabila pemimpin menerapkan budaya organisasi dalam setiap kebijakannya.

Berdasarkan pada pengolahan data tingkat tiga diperoleh bobot dari setiap elemen aktor terhadap masing-masing faktor yang berpengaruh terhadap model internalisasi budaya organisasi di IPB. Aktor yang paling berpengaruh dalam komponen informasi adalah Ketua Departemen dengan bobot 0,350. Ketua Departemen merupakan salah satu aktor yang paling berpengaruh dalam penyampaian informasi kepada bawahan atau karyawan. Aktor kedua yang berpengaruh adalah Dekan yang mempunyai bobot 0,222. Dekan juga merupakan pihak yang berpengaruh terhadap penyampaian informasi, di mana Dekan menyampaikan informasi dari pihak Rektorat (Direktur atau Rektor). Aktor berikutnya yang berpengaruh adalah Direktur serta Rektor dengan bobot masing-masing 0,221 dan 0,208. 
Dalam hal perilaku, aktor yang menjadi prioritas utama adalah Rektor dengan bobot 0,355 . Hal ini disebabkan karena untuk menginternalisasikan budaya organisasi diperlukan contoh serta teladan perilaku dari top management yaitu Rektor. Kemudian aktor kedua yang berpengaruh adalah Dekan yang juga menjadi contoh perilaku bagi bawahannya.

Aktor yang berpengaruh berikutnya adalah Ketua Departemen dan Direktur yang juga menjadi contoh perilaku bagi bawahannya atau karyawannya. Pada elemen Aktor dalam Hierarki Struktur Organisasi di IPB. Rektor menjadi prioritas tertinggi dalam hal hierarki dengan bobot sebesar 0,581. Hal ini disebabkan karena rektor mempunyai hierarki tertinggi dalam struktur organisasi di IPB. Aktor kedua yang menjadi prioritas selanjutnya adalah Dekan. Hal ini disebabkan karena Dekan mempunyai hierarki tertinggi dalam struktur organisasi di tingkat Fakultas. Aktor berikutnya yang berpengaruh dalam hal hierarki adalah Direktur serta Ketua Departemen yang juga mempunyai hierarki tertinggi di tingkat Direktorat serta Departemen.

Tabel 2. Prioritas Elemen Aktor yang Berperan dalam Penerapan Model Internalisasi Budaya Organisasi di IPB

\begin{tabular}{ccccc}
\hline \multirow{2}{*}{$\begin{array}{c}\text { Elemen } \\
\text { Faktor }\end{array}$} & \multicolumn{4}{c}{ Elemen Aktor } \\
\cline { 2 - 5 } & Rektor & Direktur & Dekan & Ka. Dept \\
\hline IF & 0,208 & 0,221 & 0,222 & 0,350 \\
PR & 0,355 & 0,168 & 0,261 & 0,217 \\
HR & 0,581 & 0,166 & 0,180 & 0,073 \\
KP & 0,571 & 0,104 & 0,254 & 0,070 \\
TM & 0,292 & 0,222 & 0,273 & 0,212 \\
\hline
\end{tabular}

Rektor menjadi prioritas utama dalam hal kepemimpinan dengan bobot 0,571 . Hal ini karena Rektor merupakan top management di IPB yang menjadi pengambil keputusan tertinggi juga. Aktor kedua yang menjadi prioritas utama adalah Dekan. Di mana Dekan juga merupakan pengambil keputusan tertinggi di tingkat Fakultas.

Aktor berikutnya yang berpengaruh dalam hal kepemimpinan adalah Direktur dan Ketua Departemen yang juga merupakan pimpinan tertinggi di Direktorat dan Departemen. Dalam hal tim, Rektor mempunyai prioritas tertinggi dengan bobot 0,292. Rektor sering membentuk tim-tim kerja, di mana tim-tim kerja tersebut penting dalam penginternalisasian budaya organisasi. Aktor kedua yang berpengaruh dalam hal tim adalah Dekan. Di mana Dekan juga sering membentuk tim kerja. Aktor selanjutnya yang berpengaruh adalah Direktur dan Ketua Departemen.

Pengolahan horizontal pada tingkat empat menggambarkan besarnya bobot dari tiap elemen tujuan terhadap masing-masing aktor yang terlibat dalam model internalisasi budaya organisasi di IPB. Bagi Rektor, tujuan terpenting yang ingin dicapai adalah mengembangkan organisasi dengan bobot 0,442 , karena ini merupakan sasaran terpenting bagi suatu organisasi. Tujuan yang berikutnya secara berurutan adalah mengaktualisasikan visi dan misi organisasi serta terapi organisasi. 
Direktur juga sangat memperhatikan tujuan mengembangkan organisasi sebagai tujuan utama yang ingin dicapai dengan bobot 0,352 kemudian diiringi dengan dengan tujuan mengaktualisasikan visi dan misi serta terapi organisasi.

Tabel 4. Prioritas Elemen Tujuan yang Ingin Dicapai Dalam Penerapan Model Internalisasi Budaya Organisasi di IPB.

\begin{tabular}{llll}
\hline \multirow{2}{*}{ Elemen Aktor } & \multicolumn{3}{c}{ Elemen Tujuan } \\
\cline { 2 - 4 } & AVM & KO & TO \\
\hline Rektor (R) & 0,428 & 0,442 & 0,131 \\
Direktur (DR) & 0,326 & 0,352 & 0,322 \\
Dekan (D) & 0,438 & 0,388 & 0,174 \\
Ka. Dept (K) & 0,396 & 0,236 & 0,368 \\
\hline
\end{tabular}

Keterangan:

AV : Mengatualisasikan Visi dan Misi Organisasi

KO : Mengembangkan Organisasi

TO : Terapi Organisasi

Tujuan yang terpenting bagi Dosen adalah mengaktualisasikan visi dan misi organisasi dengan bobot 0,438 , karena tujuan utama dari budaya organisasi adalah untuk mencapai visi serta misi organisasi. Tujuan yang berikutnya adalah mengembangkan organisasi serta terapi organisasi.

Ketua Departemen pun juga memperhatikan tujuan mengaktualisasikan visi dan misi organisasi dengan bobot 0,396. Kemudian diiringi dengan terapi organisasi karena Ketua Departemen lebih mengerti apa yang terjadi di tingkat terbawah organisasi. Tujuan yang terakhir bagi Ketua Departemen adalah mengembangkan organisasi.

Hasil pengolahan horizontal pada tingkat lima menunjukkan bobot untuk masingmasing elemen alternatif terhadap setiap tujuan yang ingin dicapai dalam penerapan model internalisasi budaya organisasi di IPB. Terdapat lima alternatif strategi penerapan model internalisasi budaya organisasi di IPB yaitu melalui sosialisasi, lokakarya, learning organization, forum pertemuan, dan training.

Pada Tabel 4 dapat dilihat bahwa semua tujuan dalam penerapan model internalisasi budaya organisasi akan lebih dapat diterapkan dengan merekomendasikan alternatif strategi penerapan learning organization. Artinya untuk menerapkan model internalisasi budaya organisasi diperlukan perubahan organisasi menjadi learning organization. Di mana learning organization adalah organisasi yang telah mengembangkan kemampuan untuk terus-menerus beradaptasi dan berubah karena semua anggota berperan aktif dalam mengidentifikasi dan menyelesaikan masalah-masalah yang berkaitan dengan pekerjaan, mempelajari dan menerapkan pengetahuan tersebut sewaktu mereka menjalankan pekerjaan organisasi itu. 
Tabel 4. Prioritas Elemen Alternatif yang Dapat Menjadi Rekomendasi Dalam Penyusunan Strategi Penerapan Model Internalisasi Budaya Organisasi di IPB

\begin{tabular}{lccccc}
\hline \multirow{2}{*}{$\begin{array}{l}\text { Elemen } \\
\text { Tujuan }\end{array}$} & \multicolumn{5}{c}{ Elemen Alternatif } \\
\cline { 2 - 6 } & SO & LK & LO & FP & TR \\
\hline AVM & 0.141 & 0.111 & 0.442 & 0.064 & 0.242 \\
KO & 0.073 & 0.200 & 0.400 & 0.075 & 0.251 \\
TO & 0.067 & 0.208 & 0.363 & 0.074 & 0.288 \\
\hline
\end{tabular}

Keterangan:

SO : Sosialisasi

LK : Lokakarya

LO : Learning Organization

FP : Forum Pertemuan

TR : Training

Analisis pengolahan vertikal bertujuan untuk melihat pengaruh setiap elemen pada tingkat hierarki tertentu terhadap sasaran utama (ultimate goal). Pengolahan vertikal akan menunjukkan alternatif strategi penerapan model internalisasi budaya organisasi di IPB yang dapat dipilih dan bobot yang dikandung masing-masing elemen hierarki. Hasil pengolahan vertical menunjukkan bahwa aktor yang paling terlibat dalam penerapan model internalisasi budaya organisasi di IPB adalah Rektor dengan bobot 0,451 . Rektor merupakan top management yang paling bertanggung jawab terhadap setiap kebijakan yang dikeluarkan yang berkaitan erat dengan internalisasi budaya organisasi. Rektor juga menjadi contoh dalam penginternalisasian budaya organisasi bagi semua karyawan yang ada di IPB.

Dekan, Direktur, dan Ketua Departemen menjadi aktor yang selanjutnya berperan dalam penerapan budaya organisasi dengan bobot masing-masing $0,245,0,152$, dan 0,152. Dekan, Direktur, dan Ketua Departemen akan menjadi penentu diterapkannya model internalisasi budaya organisasi di IPB dalam kondisi kerja nyata sehari-hari.

Pengolahan vertikal berikutnya berkaitan dengan tujuan yang ingin dicapai dalam penerapan model internalisasi budaya organisasi di IPB. Berdasarkan tujuan yang ingin dicapai, mengaktualisasikan visi dan misi organisasi menjadi prioritas tertinggi dengan bobot 0,410. Hal ini disebabkan karena salah satu tujuan utama dari penerapan budaya organisasi adalah mencapai atau mewujudkan visi dan misi organisasi atau dengan kata lain budaya organisasi adalah alat pencapaian visi dan misi organisasi.

Tujuan yang selanjutnya adalah mengembangkan organisasi serta sebagai terapi organisasi dengan bobot masing-masing 0,384 dan 0,207. Untuk mengembangkan organisasi, budaya organisasi dapat dilakukan dengan review, revision, dan reenginering. Perubahan-perubahan itu dilakukan secara bertahap dan perlahan demi perkembangan organisasi. Selain itu, budaya organisasi dirancang sebagai alat terapi organisasi. Terapi organisasi ini dilakukan apabila organisasi mengalami masalah yang memerlukan penanganan dengan segera.

Hasil pengolahan vertikal menunjukan bobot untuk masing-masing elemen alternatif terhadap strategi penerapan model internalisasi budaya organisasi di IPB. Alternatif dengan penerapan learning organization dirasa lebih tepat untuk dipilih dalam menerapkan model internalisasi budaya organisasi di IPB dengan bobot 0,410.

3.3. Rekomendasi Model Internalisasi Budaya Organisasi di IPB. 
Efektivitas penerapan budaya organisasi sangat ditentukan oleh internalisasi budaya organisasi yang digunakan. Untuk itu dibutuhkan suatu model internalisasi budaya organisasi yang efektif yang diharapkan akan mampu meningkatkan kualitas organisasi secara utuh. Selanjutnya diharapkan hal tersebut akan berdampak pada kesuksesan jangka panjang.

Berdasarkan dari analisis yang telah dilakukan mengenai model internalisasi budaya organisasi di IPB, maka dapat dilihat bahwa penerapan dengan Learning Organization menjadi prioritas utama yang dipilih dalam penerapan model internalisasi budaya organisasi di IPB. Penerapan dengan Learning Organization adalah dengan mengubah organisasi menjadi Learning Organization. Perubahan ini mencakup cara internalisasi yang diterapkan, komponen penerapan budaya organisasi, serta ukuran keberhasilan (Tabel 5).

1. Cara Internalisasi yang Diterapkan Learning Organization adalah organisasi yang telah mengembangkan kemampuan untuk terus-menerus beradaptasi dan berubah karena semua anggota berperan aktif dalam mengidentifikasi dan menyelesaikan masalah-masalah yang berkaitan dengan pekerjaan, mempelajari dan menerapkan pengetahuan tersebut sewaktu mereka menjalankan pekerjaan organisasi itu.

2. Internalisasi budaya organisasi dengan menerapkan Learning Organization memerlukan beberapa komponen penerapan. Komponen penerapan tersebut meliputi informasi, perilaku, hierarki, kepemimpinan dan tim. Komponenkomponen tersebut antara satu dan lainnya saling berkaitan dan mendukung untuk internalisasi budaya organisasi.

3. Ukuran keberhasilan dari sebuah internalisasi budaya organisasi sangat bergantung pada waktu yang digunakan. Semakin lama budaya organisasi itu diterapkan, semakin terinternalisasi pula budaya organisasi tersebut pada anggota organisasinya. Pada jangka pendek budaya organisasi hanya dapat disosialisasikan. Pada jangka panjang budaya organisasi akan terinternalisasi dan setiap anggota organisasi dapat menerapkan budaya organisasi dalam kegiatannya sehari-hari.

Tabel 5. Matriks Implikasi Manajerial

\begin{tabular}{|c|c|c|}
\hline Pembanding & Kondisi Sekarang & Learning Organization \\
\hline $\begin{array}{l}\text { 1. Cara Internalisasi yang } \\
\text { diterapkan }\end{array}$ & Belum Ada & $\begin{array}{l}\text { Dengan menerapkan Learning } \\
\text { Organization }\end{array}$ \\
\hline $\begin{array}{l}\text { 2. Komponen Penerapan } \\
\text { Budaya Organisasi }\end{array}$ & $\begin{array}{l}\text { Informasi; Perilaku; Hirarki; } \\
\text { Kepemimpinan; Tim }\end{array}$ & $\begin{array}{l}\text { Informasi; Perilaku; Hirarki; } \\
\text { Kepemimpinan; Tim }\end{array}$ \\
\hline 3. Ukuran Keberhasilan & Sosialisasi budaya organisasi & $\begin{array}{l}\text { Internalisasi budaya organisasi } \\
\text { di seluruh lapisan IPB }\end{array}$ \\
\hline
\end{tabular}

Learning Organization ini termanifestasi melalui tiga tipe pembelajar, yaitu individual, tim atau kelompok dan organisasi. Pada tingkatan individu, pembelajaran dimaksudkan untuk meningkatkan keterampilan pengetahuan, sikap dan nilai-nilai yang dibutuhkan oleh seseorang melalui pelatihan, belajar sendiri, pemahaman, observasi dan refleksi diri. Budaya organisasi yang diterapkan di IPB haruslah relevan dengan konteks organisasi pembelajar. Nilai budaya yang dipakai sangat menekankan pada keberagaman yang didasarkan pada perbedaan karyawan. Hal ini berarti bahwa setiap individu dilihat mempunyai potensi untu mengembangkan usaha. Organisasi pembelajar senantiasa memberikan ruang inovasi dan kreativitas. Inovasi dapat 
muncul melalui percakapan dan pengambilan tindakan yang nyata. Percakapan berfungsi sebagai penyumbang inovasi serta koordinasi. Syarat utama percakapan yang mampu menghasilkan inovasi adalah kondisi di mana karyawan dapat berbicara dari hati nuraninya dan berhubungan dengan yang lainnya dalam semangat berdialog tentang persoalan-persoalan organisasi yang dihadapinya. Kretivitas akan muncul jika karyawan diberikan ruang kebebasan untuk berpikir, menantang wisdom dan berpikir dengan cara baru (Marquadt, 2003).

Pada tingkatan tim atau kelompok, dimaksudkan untuk meningkatkan pengetahuan, keterampilan dan kompetensi oleh dan di dalam kelompok. Pembelajaran tim dapat terjadi melalui upaya-upaya penyelesaian konflik dengan menyatukan sudut pandang yang berbeda ke dalam pemahaman yang dapat diterima tanpa kompromi (integrating perspectives). Pembelajaran tim juga dapat berlangsung melalui uji coba terhadap satu hipotesis atau menemukan sesuatu yang baru (experimenting), dua atau lebih orang atau tim berkomunikasi untuk mencapai satu tujuan yang positif (crossing boundaries).

Terkadang tim belajar beranggapan bahwa beragamnya kelompok dan kondisi organisasi mempengaruhi pembelajaran tim serta menentukan apakah menjadi organisasi pemebelajar atau tidak. Beberapa faktor yang dapat mempengaruhi pembelajaran antara lain bila tidak ada penghargaan terhadap tim kerja, peluang bagi seseorang untuk berekspresi dan prinsip-prinsip operasional.

Apresiasi terhadap tim kerja mencakup penerimaan tim akan berbagai perbedaan pandangan dan ide-ide, tingkat di mana tim dinilai melalui individu dan cara tim dibangun atas sinergi para anggota. Peluang bagi individu untuk berekspresi di antaranya dalam bentuk peluang memberi masukan ke dalam misi, sasaran dan prosedur pelaksanaan, iklim mengekspresikan tujuan-tujuannya dan kemudahan peluang bagi anggota organisasi untuk mengekspresikan diri mereka selama aktivitas tim berlangsung. Pada dasarnya tim kerja di dalam system organisasi disesuaikan dengan budaya, nilai-nilai, misi, strategi, norma-norma, praktik manajerial, proses, dan sebagainya.

Visi mengungkapkan tujuan, sasaran, dan arah yang ingin dituju oleh organisasi. Visi organisasi pembelajar mengungkapkan pentingnya pembelajaran untuk mencapai sasaran masa depan yang diinginkan, membangun keinginan organisasi, memperbarui organisasi secara terus-menerus dalam rangka mempertahankan pertumbuhan dan perkembangannya. Strategi mengacu kepada tindakan, taktik dan metode yang digunakan untuk mencapai visi dan sasaran organisasi. Strategi dalam organisasi pembelajar mendorong dan memaksimalkan pembelajaran yang diperlukan, pentransferan dan pemanfaatan oleh seluruh Departemen, serta tindakan dan inisiatif organisasi. Sementara itu, struktur organisasi mencakup konfigurasi unit, departemen, dan divisi. Organisasi pembelajar menunjukan struktur yang sederhana yang meminimalkan pemisahan antara orang dengan proses, sambil memaksimalkan kontak, alur informasi dan kolaborasi di antara individu dan tim. 


\section{Kesimpulan}

Budaya organisasi IPB termasuk ke dalam beberapa jenis budaya organisasi atau merupakan campuran dari beberapa jenis budaya organisasi yaitu power culture, person culture, dan achievement culture.

Penerapan budaya organisasi di IPB belum dilaksanakan secara maksimal karena budaya organisasi di IPB baru disosialisasikan sekali dan belum ada sosialisasi lanjutan serta belum ada program-program internalisasinya.

Penerapan model internalisasi budaya organisasi dengan menerapkan learning organization menjadi alternatif strategi yang direkomendasikan kepada pihak IPB. Dengan penerapan learning organization, karyawan atau anggota organisasi dapat berperan aktif dalam mengidentifikasi dan menyelesaikan masalah-masalah yang berkaitan dengan pekerjaan, mempelajari dan menerapkan pengetahuan tersebut sewaktu mereka menjalankan pekerjaan organisasi tersebut.

\section{Daftar Pustaka}

Budihardjo, Andreas. 2003. 'Peranan Budaya Perusahaan: Suatu Pendekatan Sistematik dalam Mengelola Perusahaan', Prasetya Mulya Management Journal, vol. 8, no. 14, pp. 51-56.

Fewidarto, Pramono D. 1996. Proses Hirarki Analitik (Analytical Hierarchy Process), Materi pada Kursus Singkat Teknologi Industri Pertanian, Program Pascasarjana, IPB. 21 Desember 1996, Bogor.

Marquadt, Michael. 1996. The Learning Organization; a System Approach to Quantum Improvement and Global Success, McGraw-Hill, New York.

Martono, Ricky V dan Tjiu H. Kusuma. 2005. 'Penerapan Metode Analytical Hierarchy Process sebagai Pendekatan dalam Penentuan Daerah Investasi', Prasetya Mulya Management Journal Vol. 10, no. 1, pp. 86-94.

Muluk, Khairul. 2001. 'Budaya Organisasi Pelayanan Publik (Kasus pada Rumah Sakit X di Malang)', Jurnal Ilmiah Administrasi Publik FIA Unibraw, vol. 1, no. 2, pp. 1-13.

Ndraha, Taliziduhu. 2005. Teori Budaya Organisasi, Rineka Cipta, Jakarta.

Robbins, Stephen P. 2003. Essential of Organizational Behavior, 8th edition. Pearson Prentice Hall, United State.

Saaty, Th. 1993. Pengambilan Keputusan bagi Para Pemimpin, PT. Pustaka Binaman Pressindo, Jakarta.

Senge, Peter. 1995. Learning Organization; Developing Cultures for Tomorrow Workplace, Productivity Press.

Wirawan. 2008. Budaya dan Iklim Organisasi: Teori Aplikasi dan Penelitian, Salemba Empat, Jakarta. 